\title{
Tillage Effects on Soil Quality after Three Years of Irrigation in Northern Spain
}

\author{
Marcos Apesteguía ${ }^{1,2}$, Iñigo Virto ${ }^{1, *}$, Luis Orcaray ${ }^{2}$, Paloma Bescansa ${ }^{1}$, Alberto Enrique ${ }^{1}$, \\ María José $\operatorname{Imaz}^{3}$ and Douglas L. Karlen ${ }^{4}$ \\ 1 Departamento Ciencias del Medio Natural, ETSIA, Universidad Pública de Navarra, 31006 Pamplona, Spain; \\ mapesteguia@intiasa.es (M.A.); bescansa@unavarra.es (P.B.); alberto.enrique@unavarra.es (A.E.) \\ 2 Área de Innovación, Sección de Sistemas Sostenibles, Instituto Navarro de Tecnologías e Infraestructuras \\ Agroalimentarias, 31610 Villava, Spain; lorcaray@intiasa.es \\ 3 Ekoizpen Urduña, Foru Plaza, 1, 48460 Urduña-Orduña, Spain; ekoizpen@urduna.com \\ 4 USDA-Agricultural Research Service, National Laboratory for Agriculture and the Environment (NLAE), \\ 1015 North University Boulevard, Ames, IA 50011-3166, USA; doug.karlen@ars.usda.gov \\ * Correspondence: inigo.virto@unavarra.es; Tel.: +34-948-169166
}

Received: 16 June 2017; Accepted: 15 August 2017; Published: 21 August 2017

\begin{abstract}
Irrigation is being initiated on large areas of traditionally rainfed land to meet increasing global demand for food, feed, fiber and fuel. However, the consequences of this transition on soil quality (SQ) have scarcely been studied. Therefore, after previously identifying the most tillage-sensitive SQ indicators under long-term rainfed conditions, conversion of a research site on a Haplic Calcisol in Navarre, in northeast Spain provided an ideal location to reevaluate those SQ indicators after three years of irrigated management. The Soil Management Assessment Framework (SMAF) was used to test our hypothesis that adopting irrigation could change the sensitivity and importance of non-irrigated SQ indicators. Several soil physical, chemical, and biological indicators along with crop yields were used to evaluate SQ three years after initiating irrigation on a long-term conventional tillage (CT), minimum tillage (MT) and no-tillage (NT) study where either barley (Hordeum vulgare L.) or wheat (Triticum aestivum L.) was being grown. The results confirmed our hypothesis that irrigation would change the relative importance of various SQ indicators and suggested that some SMAF algorithms, such as those used to assess bulk density, needed to be recalibrated for these Mediterranean soils.
\end{abstract}

Keywords: Soil Management Assessment Framework (SMAF); soil organic carbon (SOC); bulk density (BD); particulate organic matter carbon (POM-C); conventional tillage (CT); minimum tillage (MT); no-tillage (NT); barley

\section{Introduction}

Soil is an important natural resource that sustains many key environmental and life-sustaining processes. Various approaches for soil quality (SQ) evaluation have been proposed to help ensure its protection against degradation through inappropriate agricultural management practices [1-5]. Being aware of soil physical, chemical, and biological functioning is a basic step for soil conservation, especially in intensely managed agroecosystems.

The primary challenge associated with SQ assessment is that, in contrast with water and air quality, which is defined based on contaminant load, SQ cannot be directly evaluated. For instance, with regard to human welfare, the functions soil must provide (i.e., provision of food, feed, fiber and fuel; a construction medium; and sanctuary for biological diversity) are very diverse [6]. Consequently, initial discussions regarding the concept of SQ were somewhat controversial among soil scientists [7]. A first step toward consensus was achieved in 1997, when a Soil Science Society of America committee 
characterized SQ as "the capacity of a specific kind of soil to function, within natural or managed ecosystem boundaries, to sustain plant and animal productivity, maintain or enhance water and air quality, and support human health and habitation" [8]. This definition supported the multifunctional vision of soil, in contrast to previous visions focused solely on crop production [9]. To quantitatively evaluate these critical functions, SQ indicators must be selected and assessment tools must be developed. The use of indicators to monitor SQ was first applied using pedotransfer functions [10]. Doran and Parkin [11] later described those indicators as soil properties and processes with the greatest sensitivity to changes in the critical soil functions. According to these authors, indicators should correlate well with ecosystem processes, integrate soil properties and processes, be accessible to many users, be sensitive to management and climate changes, and, when possible, be components of existing databases. Unfortunately, selection of a minimum data set (MDS) of SQ indicators cannot be universal because of the site-specific nature of soils and multitude of different functions they must perform. Therefore, MDS selection for SQ assessment must be determined by which functions are most critical to meet management goals $[12,13]$. Furthermore, because of the site-specific nature of SQ, different soil property measurements may be required for a specific function (e.g., productivity) depending upon the agroecosystem for which the assessment is being made [14-18]. Selection of proper SQ indicators must therefore be carefully accomplished for different situations, taking into account changes in land-use, soil management, or hydrologic conditions that may affect SQ.

To address the complexity of SQ evaluation, the use of soil management assessment tools and integrative indexes that included biological, chemical and physical soil data, was an interesting advance for assessing sustainability of soil ecosystem management [19]. As a result, various soil management assessment tools have been proposed. The Soil Management Assessment Framework (SMAF) proposed by [13] has been tested in a wide variety of locations throughout the U.S., including Georgia, California, and the Pacific Northwest [13,20], Colorado [21], Iowa and Wisconsin [22-24], and the Great Plains [25], and worldwide [26-29]. When compared with other assessment tools, the SMAF has demonstrated a high sensitivity for differentiating contrasting soil management practices [21]. The SMAF is based on quantifying effects of soil and crop management on dynamic soil properties and overall soil functioning. It is designed to follow a three-step system: (1) indicator selection; (2) indicator assessment; and (3) integration into a SQ index value. In the first step, SMAF serves as an expert system to help select appropriate SQ indicators for the targeted management goals, associated soil functions, and site-specific factors including region, crop climate, sampling time and analytical methods [30]. Non-linear algorithms or scoring curves for up to 14 indicators are currently incorporated in the SMAF, although effective assessments can be made with as few as five representative indicators [31]. The scoring curves convert measured values for the selected indicators into relative values ranging from 0 to 1 . A relative score of 0 is attributed to the values of the soil indicator at which the soil cannot accomplish the functions considered at all. A relative score of 1 means that the indicator is non-limiting with regard to the specific soil function (e.g., crop yield) being evaluated [13]. After scoring each indicator, the relative values of the individual indicators can be averaged into an overall index, which can be used for quantitative comparisons of soil management strategies on the same soil resources and for temporal comparisons within the same field, watershed, or other sampling location.

Semi-arid Mediterranean agroecosystems have been shown to have different degrees of SQ, mostly due to human pressure [32]. Many of these systems are set on soils containing carbonates, which are known to significantly affect several soil processes [33]. For example, carbonate-containing soils display alkaline $\mathrm{pH}$ and an exchange complex dominated by calcium, which has consequences in the availability of plant nutrients [34,35]. In relation to the soil physical characteristics, carbonates are known agents of structure stabilization [36,37]. The relationship of soil structure and organic matter cycling is also modified by the presence of carbonates [38,39]. In this sense, SQ indicators associated with the soil organic fraction and physical condition were very effective for evaluating effects of intensive dryland cereal production in NE Spain [40] and showing that changes in management can significantly improve SQ [41]. 
An emerging change for arable crop production systems in this region is the introduction of irrigation, as the overall area of irrigated land within the Mediterranean region is expected to triple during the next few decades. For example, in Navarre (NE Spain), a new irrigation canal has increased the irrigated land area by 22,000 ha in the past five years. In relation to soils and SQ, irrigation is a major change in "soil climate", with potential effects in soils. These effects have been reported not only on the organic $C$ and chemical fertility of the soil [42,43], but also on its physical condition [44] and biological indicators [45]. Previous studies in the area have shown that the turn-over rates of organic $C$ can be accelerated in the short-term [46], very likely because of changes induced in the shoot-to-root ratios of some crops, and the less limiting conditions for soil $\mathrm{C}$ mineralization. In addition, inorganic $C$ dynamics can be affected [47]. These observations are in line with previous studies conducted in other regions where changes in the total organic $C$ stored in the soil have been observed following the adoption of irrigation [48,49]. These changes are not always related to changes in crop yields [50,51], as this is also related to soil type and crops management. For instance, soil C losses associated to the implementation of irrigation have been reported in other semi-arid areas [52]. Modeling scenarios also point out the possibility of $C$ losses upon irrigation adoption in the long term [53,54]. To date, the consequences of introducing irrigation on SQ indicators in the region and an overall SQ assessment under irrigation have not been addressed. In this framework, it can be hypothesized that changes in SQ indicators will occur following the introduction of irrigation, as observed in other agrosystems [55].

Previous research in the region of Navarre using the SMAF approach for the identification of sensitive SQ indicators showed that particulate organic matter (POM), penetration resistance (PR), aggregate stability and total organic $\mathrm{C}(\mathrm{SOC})$ were the most sensitive indicators for evaluating tillage effects associated with rainfed cereal cropping [18]. Our hypothesis for this study was that implementing irrigation would reduce the sensitivity of those indicators because of their strong dependence on the soil organic C cycle $[18,40,56]$. The SMAF algorithms developed by [13] are based on soil function so that soil biological, chemical, and physical effects can be examined together and monitored over time. Because our definition of SQ (soil health) focuses on the intersection of soil biological, chemical, and physical properties and processes, simply looking at any single or select group of indicators independently may or may not identify a limiting factor, but it does not provide the integrated assessment associated by definition with SQ. This is the only known tool that has been demonstrated to successfully quantify the integrative effects on soil resources that changes in soil and crop management practices within agroecosystems can have. We also selected the SMAF to determine if the algorithms, which are adjusted automatically based on input date regarding inherent soil properties and processes, would provide information that helped producers understand the changes occurring in their soils as they convert their management practices to those associated with irrigated agriculture. In this sense, we hypothesized that SMAF algorithms would be useful for evaluating SQ response to various tillage systems three years after the conversion to irrigated management practices.

Our two primary objectives were to: (i) verify the reliability of SQ indicators selected as sensitive or adequate for evaluating SQ response to tillage under dryland conditions following conversion to irrigated management; and (ii) further evaluate the effectiveness of the SMAF for evaluating SQ response under irrigated conditions. We followed a step-wise protocol to: (1) identify the most sensitive SQ indicators as previously in dryland conditions [18]; and then (2) compare the indicators selected under the two conditions; (3) evaluate the overall SQ associated with the irrigated tillage treatments; and (4) determine if the SMAF is an appropriate SQ assessment tool for irrigated Mediterranean conditions.

\section{Materials and Methods}

\subsection{Experimental Site and Experimental Design}

The experimental site, located in Olite (Navarre, NE Spain) $\left(42^{\circ} 27^{\prime} 19^{\prime \prime} \mathrm{N} ; 18^{\circ} 10^{\prime} 00^{\prime \prime} \mathrm{W} ; 402 \mathrm{~m}\right.$ a.s.l.), was established in 1994 to evaluate different tillage treatments for rainfed barley and wheat production. 
The experiment location was reported in [56]. The experimental design was a randomized block with four replications. Plots were $9 \mathrm{~m} \times 24 \mathrm{~m}$ in size. The soil is a Haplic Calcisol [57] with a fine-clayey texture in the upper horizon (see [18] for soil characteristics). Climate is described as dry sub-humid $\left(\mathrm{C}^{1} \mathrm{~B}^{\prime} 2 \mathrm{db}^{\prime} 4\right.$ according to the classification of Thornthwaite [58]. Mean annual evapotranspiration is $740 \mathrm{~mm}$ and mean annual temperature is $13.5^{\circ} \mathrm{C}$. The average annual precipitation is $525 \mathrm{~mm}, 82 \%$ of which falls during the barley growing season (November-June).

In response to the development of a regional irrigation plan, the site became irrigated in 2009 (15 years after its implementation). However, the long-term tillage treatments were maintained. Three soil management treatments were evaluated: Conventional tillage (CT), minimum tillage (MT), and no-tillage (NT). Barley was sown each year since irrigation started at a seeding rate of $160 \mathrm{~kg} \mathrm{ha}^{-1}$ for all three treatments. Previously, barley had been grown under dryland conditions, with wheat introduced sporadically. Conventional tillage consisted of moldboard plowing $(25 \mathrm{~cm}$ deep) in late summer, followed by secondary tillage with a harrow for seedbed preparation before seeding (late October). Crop residues were incorporated into the arable layer during tillage. Seeding was accomplished using a coulter-seeder. Minimum tillage consisted of chisel plowing $(15 \mathrm{~cm}$ deep) and secondary tillage and seeding as for CT. A direct seeder that opened a seed-furrow 3-5 cm deep was used for NT. Nitrogen and P fertilization rates were similar for all three tillage treatments, averaging 100-27-0 kg N-P-K ha ${ }^{-1}$ year $^{-1}$. Superphosphate was used as basal dressing in September every other year. Urea was used every year for $\mathrm{N}$ fertilization. Fertilizers were applied following the standard methods in the region. Weeds were controlled equally for all treatments with conventional herbicides (Glyphosate $\left(\mathrm{C}_{3} \mathrm{H}_{8} \mathrm{NO}_{5} \mathrm{P}, \mathrm{N}\right.$-(Phosphonomethyl)glycine $36 \%, 2 \mathrm{~L} \mathrm{ha}^{-1}$ in preseeding, isoproturon $\left(\mathrm{C}_{12} \mathrm{H}_{18} \mathrm{~N}_{2} \mathrm{O}\right.$, 3-(4-isopropylphenyl)-1,1-dimethylurea) $50 \%$, $3 \mathrm{~L} \mathrm{ha}^{-1}$ in November-December, and Pinoxaden $\left(\mathrm{C}_{23} \mathrm{H}_{32} \mathrm{~N}_{2} \mathrm{O}_{4}, 8\right.$-(2,6-diethyl-4-methylphenyl)-9-oxo$1 H, 2 H, 4 H, 5 H$-pyrazolo[1,2-d][1,4,5]oxadiazepin-7-yl 2,2-dimethylpropanoate) $6 \%, \quad 0.8 \mathrm{~L} \mathrm{ha}^{-1}$ when needed).

Irrigation was managed using sprinklers especially set to grant uniform water spreading in all treatments. Irrigation needs were determined following the weekly recommendations of the Extension Service in the region [59], which provides information based on meteorological data and basic soil water balances, and was applied in the months of April, May and June. The average doses applied accounted for 40-60 $\mathrm{L} \mathrm{m}^{-2}$, split into 1-2 weekly doses in April, 75-100 L m ${ }^{-2}$ split into 2-3 weekly doses in May, and 15-20 L m${ }^{-2}$ in the first week of June.

\subsection{Soil and Crop Sampling}

To account for all the possible changes induced by irrigation, soil samples were collected at the end of the third growing season after the conversion to irrigation, from the $0-5$ and 5-15 cm depth increments, in three different episodes. First, samples were collected in spring (May) to measure earthworm and microbial biomass, as spring was previously identified as the period with the highest earthworms biomass [40], and it corresponded with the warmest period of the growing season in which water was added with irrigation to grant adequate soil moisture. For earthworms, two $20 \times 20 \times 20 \mathrm{~cm}$ soil blocks were extracted from each treatment in all replicates. Another set of soil cores for the $0-5$ and 5-15 cm depth increments were also collected and kept refrigerated until they could be homogenized for microbial biomass analysis as described below. Then, at the end of the campaign (June), five subsamples were collected per plot for each depth using an Edelman type auger $(\varnothing=5 \mathrm{~cm})$, and combined to obtain a composite sample for chemical and physical analyses at the end of the growing season. Immediately after sampling, a portion of the composite soil sample was gently pushed through an $8 \mathrm{~mm}$ sieve. These aggregates were allowed to air dry and used for aggregate stability analyses (see Section 2.3.1). The remainder of the soil was air-dried and ground to pass a $2 \mathrm{~mm}$ sieve. Finally, intact soil cores were also collected later on, when the soil was at the adequate moisture content to avoid compaction by sampling, using bevel-edged steel rings $(\varnothing=5 \mathrm{~cm}$, total 
volume $=100 \mathrm{~cm}^{3}$ ) for the $0-5$ and $5-15 \mathrm{~cm}$ depths to determine soil bulk density (BD) and the soil water retention characteristics.

Throughout the period of record (2010-2012), barley was harvested each year with plot-scale combines and grain yields were recorded. Grain weights were taken directly on the combine and grain samples from each treatment were collected and analyzed to determine water content. Grain yields were then adjusted to a water content of $120 \mathrm{~g} \mathrm{~kg}^{-1}$. Before harvesting, crop biomass was sampled in three $1-\mathrm{m}^{2}$ squares per plot. The total amount of $C$ added to the soil from crop residues was calculated by correcting for the biomass exported with harvesting, its average $\mathrm{C}$ concentration $(40.8 \%)$, and using standard aerial-to-root biomass ratios [60].

\subsection{Soil Analyses}

Selected soil physical, chemical and biological properties were measured as potential SQ indicators. Pre-selection of the indicators was based on soil properties previously detected in the same experimental field and shown to represent soil functions that were sensitive to management under dryland conditions and influenced crop yield [18].

\subsubsection{Physical Properties}

Bulk density (BD), penetration resistance (PR) and soil aggregate stability using different indexes (see below) were measured as the physical soil properties. Available water-holding capacity of the soil (AWHC) was also measured for SMAF analysis.

The core method was used to determine BD [61]. Penetration resistance was measured six months after seeding at nine points per field replicate to a depth of $60 \mathrm{~cm}$ using a field penetrometer (Rimik CP20, Agridy Rimik Pty Ltd., Toowoomba, QLD, Australia). Measurements were made after a rainy period to avoid differences in water content between treatments. Measurements were recorded every $15 \mathrm{~mm}$, and PR for 0 to 5 and 5 to $15 \mathrm{~cm}$ were calculated as weighted depth averages. Dry aggregate stability was determined by placing $100 \mathrm{~g}$ of dry aggregates $(<8 \mathrm{~mm})$ in the top of a column of sieves of $6.3,4,2,1,0.5$ and $0.25 \mathrm{~mm}$ openings and shaking the whole in a rotary movement at 60 strokes/min for $60 \mathrm{~s}$ in a Retsch VS 100 device (Retsch GmbH \& Co., Haan, Germany). For wet aggregate stability, a constant shower-like flux $(6 \mathrm{~L} / \mathrm{min})$ of distilled water was applied from the top of the same set of sieves while sieving $(60$ strokes $/ \mathrm{min}, 60 \mathrm{~s})$. We used a mechanical sample divisor (Retsch $\mathrm{GmbH} \& \mathrm{Co}$., Haan, Germany) to ensure that initial distribution of aggregates was similar. Aggregate size-distribution was expressed as the mean weight diameter (MWD) after dry and wet sieving. Stability of the aggregates was evaluated using a ratio of wet-to-dry MWD (MWDw/MWDd) [62,63]. For SQ evaluation with SMAF, the proportion of water-stable aggregates bigger than $0.25 \mathrm{~mm}$ (WSA) was obtained after wet sieving.

Soil water retention at $-33 \mathrm{kPa}$ was determined on intact soil cores, and sieved $(<2 \mathrm{~mm})$ soil samples were used for water retention assessment at $-1500 \mathrm{kPa}$. Samples were placed on pressure plate extractors (Soil Moisture Equipment Corp., Santa Barbara, CA, USA). Volumetric water was calculated using BD. Available water-holding capacity was calculated as the difference between volumetric water content at field capacity $(-33 \mathrm{kPa})$ and wilting point $(-1500 \mathrm{kPa})$.

\subsubsection{Chemical Properties}

All chemical analyses were done on air-dry sieved $(<2 \mathrm{~mm})$ samples. Total $\mathrm{N}$ was determined using the Kjeldahl digestion method. Available $\mathrm{P}$ was determined as described by Olsen and Sommers [64]. Exchangeable $\mathrm{K}$ was quantified using atomic absorbance after extraction with $\mathrm{NH}_{4} \mathrm{OAc}$ $1 \mathrm{~N}$ [65]. Soil electrical conductivity (EC) and soil $\mathrm{pH}$ were measured in distilled water (1:2.5). Soil $\mathrm{pH}$ was determined with a Crison GLP22 pH meter (Crison Instruments, S.A., Barcelona, Spain). Conductivity was read with a Crison GLP32 conductivity meter (Crison Instruments, S.A., Barcelona, Spain). Carbonates concentration was measured in a Bernard's calcimeter by quantifying the $\mathrm{CO}_{2}$ produced after treating a soil sample with $\mathrm{HCl}$. 


\subsubsection{Organic Matter and Soil Biological Properties}

Soil organic C (SOC) was determined by wet oxidation on air-dry sieved $(<2 \mathrm{~mm})$ samples [66]. The fraction of soil organic matter defined as particulate organic matter (POM) based on its size $(>53 \mu \mathrm{m})$ [67] was isolated by dispersion and sieving of $10 \mathrm{~g}$ of air dried soil, using the method described in [40]. Earthworms were collected in May as the barley reached physiological maturity by crumbling the $20 \times 20 \times 20 \mathrm{~cm}$ soil blocks by hand, placing the worms in a glass jar, and weighing to obtain a fresh weight for each treatment [68]. Previous studies determined that Scherotheca gigas (Dugés 1828) is the predominant anecic species in the area [69]. Microbial biomass carbon (MBC) was measured by comparing extractable $\mathrm{C}$ from non-fumigated and chloroform $\left(\mathrm{CHCl}_{3}\right)$-fumigated soil [70]. Carbon concentration in the extract (chromic acid dissolution) was analyzed by sulfuric digestion and subsequent spectrophotometry.

\subsection{Selection of Soil Quality Indicators}

Selection of the most sensitive SQ indicators as a minimum data set (MDS) for this particular soil and soil use (i.e., irrigated crop production) was done as described by [18] for dryland conditions. A univariate analysis of variance (ANOVA) for the different soil variables was used to identify significant tillage treatment and depth effects. Only those variables for which the F statistic for soil management was significant $(p<0.05)$ were retained for further analysis. Earthworm biomass was included as an indicator because previous studies in this field had shown a direct relationship between earthworm activity and surface residue [69]. Factor analysis was then used to group the retained variables based on their correlation structure. Principal component analysis (PCA) was used for factor extraction [71]. To eliminate the effect of different units of variables, factor analysis was done using the correlation matrix on the standardized values of the measured soil properties, so that each variable had a mean $=0$ and variance $=1$ (total variance $=$ number of variables [16]). We used the matrix to identify the existence of correlations between different soil properties.

Principal components (factors) with eigenvalues $>1$ were retained and subjected to varimax rotation with Kaiser to estimate the proportion of the variance of each property explained by each selected factor (loadings), and by all factors (communalities). This was done because less importance should be ascribed to soil properties with low communalities when interpreting principle component factors [71]. To evaluate the effects of tillage treatments, factor scores for each sample point were calculated and ANOVA was performed on the new score variables. Homogeneous groups among treatments were detected using Duncan's test ( $p<0.05$, unless otherwise indicated). Only factors that differed among treatments were retained for further consideration. Soil properties were then assigned to the factor for which their loading was the highest [16]. For each retained factor, highly weighted properties were selected as possible SQ indicators. We considered highly weighted as those within $10 \%$ of the highest factor loading $[15,20]$. All statistical treatments were performed using IBM SPSS Statistics 21.0 (SPSS Inc., 2016, Chicago, IL, USA).

\subsection{Soil Quality Evaluation with SMAF}

The SMAF algorithms developed by $[13,19]$ were also used for SQ evaluation. To begin, several soil and ecosystem parameters (organic matter class, texture class, clay concentration, mineral class, $\mathrm{Fe}_{2} \mathrm{O}_{3}$ class, climate class, season code, region code, crop code, rotation code, slope class, weathering class, P extraction method and EC method) were selected to adjust the algorithms to our local conditions. Measured values for several physical, chemical and biological soil properties that have scoring algorithms, (i.e., BD, PR, AWHC, WSA, available P, extractable $\mathrm{K}, \mathrm{pH}, \mathrm{EC}$, SOC and MBC) were recorded in the Excel spreadsheet. These soil properties were used regardless of their significance in the previous analysis because: (i) the SQ index proposed by SMAF gives individual scores using the algorithms developed for each soil property; and (ii) SMAF generates an additive index that accounts 
for all the properties considered. Univariate ANOVA was then run to examine significant differences in the scores given by SMAF for the different soil properties and in the general SQ index generated.

\section{Results}

\subsection{Crop Yields}

Average barley grain yields $\left(4.10 \pm 0.1 \mathrm{Mg} \mathrm{ha}^{-1}\right.$ under NT, $4.38 \pm 0.4 \mathrm{Mg} \mathrm{ha}^{-1}$ under MT, and $4.47 \pm 0.8 \mathrm{Mg} \mathrm{ha}^{-1}$ under CT) were not significantly different among tillage treatments and were within the range of average local rainfed barley yields during the three-years of this study reported in [56]. Differences were not observed either in the total amount of organic $C$ incorporated into the soil among treatments $\left(2.49 \pm 0.2 \mathrm{Mg} \mathrm{C}^{-1}\right.$ under NT, $2.40 \pm 0.4 \mathrm{Mg} \mathrm{C}^{-1}$ under MT, and $2.74 \pm 0.2 \mathrm{Mg} \mathrm{C} \mathrm{ha}^{-1}$ under CT).

\subsection{Identification of Soil Quality Indicators}

ANOVA showed that some soil properties were significantly $(p<0.05)$ affected by tillage treatment. Within the $0-5 \mathrm{~cm}$ depth, seven indicators showed significant differences: BD and PR as physical properties, total $\mathrm{N}$ and extractable $\mathrm{K}$ as chemical properties, and SOC, MBC, and earthworm biomass reflecting soil organic matter and biological properties. POM-C, an active fraction of the overall SOC pool, showed significant differences at $p<0.1$, among tillage treatments (Table 1 ). Within the 5-15 cm depth, four indicators showed significant differences: BD and PR, total N and SOC (Table 2). To determine if the transition to irrigated management changed the SQ indicators that were most sensitive to tillage when compared to prior dryland assessments [18], we focused only on the soil properties that showed a statistically significant response to tillage.

Table 1. Physical (bulk density (BD), penetration resistance (PR), and mean weight diameter in dry $\left(\mathrm{MWD}_{\mathrm{d}}\right)$ and wet $\left(\mathrm{MWD}_{\mathrm{W}}\right)$ samples), chemical (total nitrogen, available phosphorous, extractable potassium, carbonates as $\mathrm{CaCO}_{3}, \mathrm{pH}$ and electrical conductivity (EC)), and organic matter and biological soil properties (total organic $\mathrm{C}(\mathrm{SOC}), \mathrm{C}-\mathrm{to}-\mathrm{N}$ ratio $(\mathrm{C} / \mathrm{N}), \mathrm{C}$ in the particulate organic fraction (POM-C), and microbial biomass carbon $(\mathrm{MBC})$ ) for the different tillage treatments in the 0-5 cm depth. Earthworms biomass at 0-20 cm. (means $(n=4) \pm$ standard error).

\begin{tabular}{|c|c|c|c|}
\hline Soil Property & No-Tillage & Minimum Tillage & Conventional Tillage \\
\hline \multicolumn{4}{|c|}{ Physical } \\
\hline $\mathrm{BD}\left(\mathrm{Mg} \mathrm{m}^{-3}\right)$ & $1.64 \pm 0.01 \mathrm{a}$ & $1.51 \pm 0.04 \mathrm{~b}$ & $1.53 \pm 0.04 b$ \\
\hline PR (MPa) & $0.87 \pm 0.02 \mathrm{a}$ & $0.41 \pm 0.10 \mathrm{~b}$ & $0.5 \pm 0.08 \mathrm{~b}$ \\
\hline $\mathrm{MWD}_{\mathrm{d}}(\mathrm{mm})$ & $4.01 \pm 0.06$ & $3.42 \pm 0.16$ & $3.67 \pm 0.33$ \\
\hline $\operatorname{MWD}_{\mathrm{w}}(\mathrm{mm})$ & $0.87 \pm 0.07$ & $0.54 \pm 0.12$ & $0.56 \pm 0.13$ \\
\hline $\mathrm{MWD}_{\mathrm{w}} / \mathrm{MWD}_{\mathrm{d}}$ & $0.22 \pm 0.01$ & $0.15 \pm 0.02$ & $0.15 \pm 0.03$ \\
\hline \multicolumn{4}{|c|}{ Chemical } \\
\hline Total N $\left(\mathrm{g} \mathrm{kg}^{-1}\right)$ & $1.88 \pm 0.05 \mathrm{a}$ & $1.53 \pm 0.06 b$ & $1.39 \pm 0.31 b$ \\
\hline Available P (ppm) & $4.32 \pm 0.09$ & $3.76 \pm 1.36$ & $2.28 \pm 0.22$ \\
\hline Extractable K (ppm) & $402 \pm 7.1 \mathrm{a}$ & $348 \pm 22 \mathrm{ab}$ & $281 \pm 29 b$ \\
\hline $\mathrm{CaCO}_{3}\left(\mathrm{~g} \mathrm{~kg}^{-1}\right)$ & $278 \pm 3.0$ & $287 \pm 4.0$ & $294 \pm 6.1$ \\
\hline $\mathrm{pH}$ & $8.45 \pm 0.02$ & $8.42 \pm 0.06$ & $8.56 \pm 0.04$ \\
\hline $\mathrm{EC}\left(\mu \mathrm{cm}^{-1}\right)$ & $211 \pm 3.0$ & $230 \pm 10$ & $211 \pm 6.0$ \\
\hline \multicolumn{4}{|c|}{ Organic matter and biological } \\
\hline $\operatorname{SOC}\left(\mathrm{g} \mathrm{kg}^{-1}\right)$ & $17.3 \pm 0.4 \mathrm{a}$ & $14.3 \pm 0.5 \mathrm{~b}$ & $10.5 \pm 0.2 c$ \\
\hline $\mathrm{C} / \mathrm{N}$ & $9.18 \pm 0.09$ & $9.33 \pm 0.18$ & $7.78 \pm 0.34$ \\
\hline POM-C $\left(\mathrm{g} \mathrm{kg}^{-1}\right)$ & $4.02 \pm 0.06 \mathrm{a}^{1}$ & $3.51 \pm 0.70 \mathrm{a}^{1}$ & $2.81 \pm 0.28 b^{1}$ \\
\hline $\operatorname{MBC}\left(\mathrm{mg} \mathrm{kg}^{-1}\right)$ & $217 \pm 17 \mathrm{a}$ & $111 \pm 10 \mathrm{~b}$ & $49 \pm 6.0 \mathrm{c}$ \\
\hline Earthworms $\left(\mathrm{g} \mathrm{m}^{-2}\right)(0-20 \mathrm{~cm})$ & $128 \pm 1.0 \mathrm{~b}$ & $198 \pm 1.1 \mathrm{a}$ & $41 \pm 1.0 \mathrm{c}$ \\
\hline
\end{tabular}

Treatment values within the same row followed by different letters are significantly different at $p<0.05 .{ }^{1}$ Different at $p<0.10$. 
Table 2. Physical (bulk density (BD), penetration resistance (PR), and mean weight diameter in dry (MWDd) and wet (MWDw) samples), chemical (total nitrogen, available phosphorous, extractable potassium, carbonates as $\mathrm{CaCO}_{3}, \mathrm{pH}$ and electrical conductivity (EC)), and organic matter and biological soil properties (total organic $\mathrm{C}(\mathrm{SOC}), \mathrm{C}-\mathrm{to}-\mathrm{N}$ ratio $(\mathrm{C} / \mathrm{N}), \mathrm{C}$ in the particulate organic fraction (POM-C), and microbial biomass carbon (MBC)) for the different tillage treatments in the 5-15 cm depth (means $(n=4) \pm$ standard error).

\begin{tabular}{|c|c|c|c|}
\hline Soil Property & No-Tillage & Minimum Tillage & Conventional Tillage \\
\hline \multicolumn{4}{|c|}{ Physical } \\
\hline $\mathrm{BD}\left(\mathrm{Mg} \mathrm{m}^{-3}\right)$ & $1.65 \pm 0.00 \mathrm{a}$ & $1.63 \pm 0.02 \mathrm{ab}$ & $1.56 \pm 0.03 b$ \\
\hline $\mathrm{PR}(\mathrm{MPa})$ & $1.56 \pm 0.03 \mathrm{a}$ & $0.69 \pm 0.14 b$ & $0.76 \pm 0.11 b$ \\
\hline $\operatorname{MWDd}(\mathrm{mm})$ & $3.78 \pm 0.09$ & $3.84 \pm 0.18$ & $4.07 \pm 0.29$ \\
\hline MWDw (mm) & $1.17 \pm 0.09$ & $1.03 \pm 0.15$ & $1.08 \pm 0.13$ \\
\hline MWDw/MWDd & $0.31 \pm 0.02$ & $0.26 \pm 0.03$ & $0.27 \pm 0.04$ \\
\hline \multicolumn{4}{|c|}{ Chemical } \\
\hline Total N $\left(\mathrm{g} \mathrm{kg}^{-1}\right)$ & $1.41 \pm 0.05 \mathrm{a}$ & $1.36 \pm 0.14 \mathrm{a}$ & $1.14 \pm 0.11 b$ \\
\hline Available P (ppm) & $2.54 \pm 0.12$ & $2.68 \pm 0.31$ & $2.66 \pm 0.48$ \\
\hline Extractable K (ppm) & $267 \pm 3.0$ & $290 \pm 9.0$ & $255 \pm 39$ \\
\hline $\mathrm{CaCO}_{3}\left(\mathrm{~g} \mathrm{~kg}^{-1}\right)$ & $286 \pm 3.0$ & $284 \pm 9.0$ & $289 \pm 9.0$ \\
\hline $\mathrm{pH}$ & $8.66 \pm 0.03$ & $8.51 \pm 0.09$ & $8.59 \pm 0.04$ \\
\hline $\mathrm{EC}\left(\mu \mathrm{sm}^{-1}\right)$ & $219 \pm 2.0$ & $216 \pm 5.0$ & $217 \pm 9.3$ \\
\hline \multicolumn{4}{|c|}{ Organic matter and biological } \\
\hline $\mathrm{SOC}\left(\mathrm{g} \mathrm{kg}^{-1}\right)$ & $11.5 \pm 0.1 \mathrm{a}$ & $12.7 \pm 0.8 \mathrm{a}$ & $9.8 \pm 0.20 \mathrm{~b}$ \\
\hline $\mathrm{C} / \mathrm{N}$ & $8.57 \pm 0.05$ & $9.38 \pm 0.45$ & $8.57 \pm 0.16$ \\
\hline POM-C $\left(\mathrm{g} \mathrm{kg}^{-1}\right)$ & $1.89 \pm 0.06$ & $1.97 \pm 0.47$ & $1.22 \pm 0.09$ \\
\hline $\mathrm{MBC}\left(\mathrm{mg} \mathrm{kg}^{-1}\right)$ & $43.5 \pm 3.4$ & $49.8 \pm 10.3$ & $30.9 \pm 1.8$ \\
\hline
\end{tabular}

Treatment values within the same row followed by different letters are significantly different at $p<0.05$.

\subsubsection{The $0-5 \mathrm{~cm}$ Depth}

The correlation matrix (determinant $<0.0001$ ) developed for the eight soil properties within the $0-5 \mathrm{~cm}$ depth increment showed significant relationships for 21 of 28 pairs (Table 3). Significant positive correlations were found between total $\mathrm{N}$ and $\mathrm{BD}$, SOC and extractable $\mathrm{K}, \mathrm{SOC}$ and $\mathrm{MBC}$, and $\mathrm{MBC}$ and extractable K. The PCA identified two factors (F1 and F2) with eigenvalues $>1$ for the $0-5 \mathrm{~cm}$ depth (Table 4). Together, those factors explained $>76 \%$ of the variability in measured soil properties.

Table 3. Correlation between measured soil properties (bulk density (BD), penetration resistance (PR), total N, extractable $\mathrm{K}$, soil organic carbon (SOC), particulate organic C (POM-C), and microbial biomass carbon $(\mathrm{MBC})$ ) and earthworms biomass $\left(\mathrm{g} \mathrm{m}^{-2}\right)$ considered for factor analysis in the $0-5 \mathrm{~cm}$ depth across all management treatments (conventional tillage, minimum tillage and no-tillage).

\begin{tabular}{cccccccc}
\hline & BD & PR & Total N & Ext. K & SOC & POM-C & MBC \\
\hline BD & 1 & & & & & & \\
PR & $0.545^{* *}$ & 1 & & & & & \\
Total N & $0.817^{* * *}$ & $0.567^{* *}$ & 1 & & & & \\
Extractable K & $0.552^{* *}$ & $0.455^{*}$ & $0.514^{*}$ & 1 & & & \\
SOC & $0.467^{*}$ & $0.585^{* *}$ & $0.688^{* *}$ & $0.786^{* * *}$ & 1 & & \\
POM-C & $0.452^{*}$ & $0.204^{* *}$ & $0.242^{*}$ & $0.601^{* *}$ & $0.453^{*}$ & 1 & \\
Earthworms & $0.659^{* *}$ & $0.643^{* *}$ & $0.725^{* *}$ & $0.781^{* * *}$ & $0.875^{* * *}$ & $0.591^{* *}$ & 1 \\
\hline
\end{tabular}

* Correlation is significant at $p<0.10,{ }^{* *}$ Correlation is significant at $p<0.05,{ }^{* * *}$ Correlation is significant at $p<0.01$. 
Table 4. Eigenvalue, percentage and cumulative variance explained by factor analysis using the correlation matrix of the standardized data of soil properties at $0-5$ and 5-15 cm depths.

\begin{tabular}{cccc}
\hline Factors & Eigenvalue $^{\mathbf{1}}$ & Percentage (\%) & Cumulative (\%) \\
\hline $0-5 \mathrm{~cm}$ & & & \\
F1 & 4.69 & 58.7 & 58.7 \\
F2 & 1.44 & 17.9 & 76.6 \\
$5-15 \mathrm{~cm}$ & & 52.2 & 52.2 \\
F3 & 2.09 & & \\
\hline
\end{tabular}

${ }^{1}$ Only factors with eigenvalues $>1$ are shown.

Factor scores were calculated and tested for significant differences in response to tillage as in [18] (Table 5). Both F1 and F2 were sensitive to tillage treatment for this soil depth. Therefore, only those soil properties with the highest proportion of variability explained by those factors were taken into account for the selection of SQ indicators in this step. These were BD and earthworm biomass for F1 and F2, respectively. PR and total $\mathrm{N}$ had loadings for F1 within 10\% of that of BD, while SOC had the second highest loading for F2. Those properties were selected as the most sensitive near-surface SQ indicators for the studied soil under irrigated management.

Table 5. Variance explained using varimax rotation for each of the retained factors, and communalities for the selected soil properties (bulk density (BD), penetration resistance (PR), total N, extractable K, soil organic carbon (SOC), microbial biomass carbon (MBC) and earthworm biomass, $\left.\mathrm{g} \mathrm{m}^{-2}\right)$ ) for the $0-5 \mathrm{~cm}$ depth, and effect of management on factor scores.

\begin{tabular}{cccc}
\hline Soil Property & F1 & F2 & Communality \\
\hline BD & 0.869 & 0.148 & 0.777 \\
PR & 0.850 & 0.033 & 0.724 \\
Total N & 0.815 & 0.294 & 0.750 \\
Extractable K & 0.507 & 0.725 & 0.783 \\
SOC & 0.552 & 0.748 & 0.864 \\
POM-C & 0.277 & 0.639 & 0.485 \\
MBC & 0.726 & 0.607 & 0.895 \\
Earthworms & -0.213 & 0.898 & 0.852 \\
\hline
\end{tabular}

\begin{tabular}{ccc}
\hline & \multicolumn{2}{c}{ Management effect } \\
ANOVA $p$-value & $<0.0001$ & $<0.0001$ \\
& Mean scores & \\
No tillage & $1.19 \mathrm{~b}$ & $0.44 \mathrm{~b}$ \\
Minimum tillage & $-0.85 \mathrm{a}$ & $0.77 \mathrm{~b}$ \\
Conventional tillage & $-0.34 \mathrm{a}$ & $-1.22 \mathrm{a}$ \\
\hline
\end{tabular}

Treatment values within the same column followed by different letters are significantly different at $p<0.05$.

\subsubsection{The $5-15 \mathrm{~cm}$ Depth}

A significant correlation matrix (determinant $<0.0001$ ) was also developed using four soil properties for the $5-15 \mathrm{~cm}$ depth. Those properties (BD, PR, total $\mathrm{N}$ and SOC) were the only ones found by ANOVA to be sensitive to management (Table 2). This identified three significant correlations out of 12 possible pairs for this depth, with the highest correlation being between BD and SOC (Table 6). The PCA identified one factor (F3) with an eigenvalue $>1$. It explained $>52 \%$ of the variability within the selected soil properties (Table 4), and had high positive loadings ( $>78 \%$ ) for BD and SOC (Table 7). F3 also showed significant $(p<0.05)$ tillage treatment differences (Table 4$)$, confirming that within this soil, BD and SOC were the most sensitive SQ indicators for this depth. 
Table 6. Correlation between measured soil properties (bulk density (BD), penetration resistance (PR), total $\mathrm{N}$, and soil organic carbon (SOC)) considered for factor analysis in the 5-15 cm depth across all management treatments (conventional tillage, minimum tillage and no-tillage).

\begin{tabular}{cccccc}
\cline { 2 - 5 } & BD & PR & N & SOC \\
\cline { 2 - 5 } & BD & 1 & & & \\
PR & $0.432 *$ & 1 & & \\
Total N & 0.271 & 0.351 & 1 & 1 \\
SOC & $0.592 * *$ & 0.221 & $0.429 *$ & 1 \\
* Correlation is significant at $p<0.10,{ }^{* *}$ Correlation is significant at $p<0.05, * *$ Correlation is significant at $p<0.01$.
\end{tabular}

Table 7. Variance explained using varimax rotation for each of the retained factors, and communalities for the selected soil properties (bulk density (BD), penetration resistance (PR), total $\mathrm{N}$ and soil organic carbon (SOC)) for the 5-15 cm depth, and effect of management on factor scores.

\begin{tabular}{ccc}
\hline Soil Property & F3 & Communality \\
\hline BD & 0.805 & 0.648 \\
PR & 0.656 & 0.430 \\
Total N & 0.678 & 0.460 \\
SOC & 0.787 & 0.620 \\
\hline \multicolumn{3}{c}{ Management effect } \\
ANOVA $p$-value & $<0.0001$ \\
Mean scores \\
No tillage & $0.89 \mathrm{~b}$ \\
Minimum tillage & $0.34 \mathrm{~b}$ \\
Conventional tillage & $-1.23 \mathrm{a}$ \\
\hline within the same column followed by different letters are significantly different at $p<0.05$.
\end{tabular}

\subsection{Assessment of Soil Quality Indicators}

A SMAF evaluation of SQ (Tables 8 and 9) was performed using BD, WSA, AWHC, available P, extractable $\mathrm{K}, \mathrm{pH}, \mathrm{EC}, \mathrm{SOC}$ and MBC. Scores for each indicator and an overall SQ index for each sampling depth were evaluated.

Within the $0-5 \mathrm{~cm}$ depth, significant tillage treatment differences were observed in scores for five SQ indicators (Table 8). Among physical indicators, the highest differences were observed for WSA, with higher scores for NT than MT or CT. Significant differences were also observed in BD scores, with NT being significantly lower than either of the other tillage treatments. Among the chemical indicators, scores for available $\mathrm{P}$ were significantly different between tillage treatments, with NT having a higher value than CT. Scores for extractable $\mathrm{K}, \mathrm{pH}$ and EC showed no differences. Furthermore, since extractable $\mathrm{K}$ and EC achieved scores of 1 , this indicates those parameters were not limiting barley production at all and therefore, for those indicators this soil was functioning at its maximum SQ potential. In contrast, SOC and MBC scores were significantly different among tillage treatments, with NT having the highest score and CT the lowest (Table 8). The overall SQ index for the $0-5 \mathrm{~cm}$ depth was significantly different for the three tillage treatments (Table 8), with NT having the highest value, followed by MT and CT, respectively.

Within the 5-15 cm depth, only two SQ indicators (BD and SOC) showed significantly different scores (Table 9). Conventional tillage had a higher BD score than NT. SOC scores within this depth were lower for CT than either MT or NT treatments. Overall, NT and MT treatments had lower SQ index values within the $5-15 \mathrm{~cm}$ depth than within the $0-5 \mathrm{~cm}$ depth, and, as a result, the differences between treatments at the $0-5 \mathrm{~cm}$ depth were not observed for the 5-15 cm depth. 
Table 8. Scores for the soil properties considered in SMAF (bulk density (BD), water-stable aggregates (WSA), available water-holding capacity (AWHC), available phosphorous, extractable $\mathrm{K}$, $\mathrm{pH}$, electrical conductivity (EC), soil organic C (SOC), and microbial biomass carbon (MBC)), and overall averaged soil quality index (SQI) value (0 to 1$)$, as affected by tillage system within the $0-5 \mathrm{~cm}$ depth increment (means $(n=4) \pm$ standard error).

\begin{tabular}{|c|c|c|c|}
\hline Soil Quality Indicator & No-Tillage & Minimum Tillage & Conventional Tillage \\
\hline \multicolumn{4}{|c|}{ Physical } \\
\hline $\mathrm{BD}\left(\mathrm{Mg} \mathrm{m}^{-3}\right)$ & $0.24 \mathrm{~b}$ & $0.31 \mathrm{a}$ & $0.30 \mathrm{ab}$ \\
\hline PR (MPa) & $0.55 \mathrm{a}$ & $0.40 \mathrm{~b}$ & $0.38 \mathrm{~b}$ \\
\hline MWDd (mm) & $0.67 \mathrm{a}$ & $0.67 \mathrm{a}$ & $0.64 \mathrm{a}$ \\
\hline \multicolumn{4}{|c|}{ Chemical } \\
\hline Total N $\left(\mathrm{g} \mathrm{kg}^{-1}\right)$ & $0.64 \mathrm{a}$ & $0.42 \mathrm{ab}$ & $0.21 \mathrm{~b}$ \\
\hline Available P (ppm) & $1.00 \mathrm{a}$ & $1.00 \mathrm{a}$ & $1.00 \mathrm{a}$ \\
\hline Extractable K (ppm) & $0.65 \mathrm{a}$ & $0.66 \mathrm{a}$ & $0.62 \mathrm{a}$ \\
\hline $\mathrm{CaCO}_{3}\left(\mathrm{~g} \mathrm{~kg}^{-1}\right)$ & $1.00 \mathrm{a}$ & $1.00 \mathrm{a}$ & $1.00 \mathrm{a}$ \\
\hline \multicolumn{4}{|c|}{ Organic matter and biological } \\
\hline $\operatorname{SOC}\left(\mathrm{g} \mathrm{kg}^{-1}\right)$ & $0.96 \mathrm{a}$ & $0.89 \mathrm{~b}$ & $0.62 c$ \\
\hline $\operatorname{MBC}\left(\mathrm{mg} \mathrm{kg}^{-1}\right)$ & $0.92 \mathrm{a}$ & $0.41 \mathrm{~b}$ & $0.10 \mathrm{c}$ \\
\hline \multicolumn{4}{|c|}{ Soil Quality Index (SQI) } \\
\hline & $0.76 \mathrm{a}$ & $0.69 \mathrm{~b}$ & $0.62 c$ \\
\hline
\end{tabular}

Treatment values within the same row followed by different letters are significantly different at $p<0.05$.

Table 9. Scores for the soil properties considered in SMAF (bulk density (BD), water-stable aggregates (WSA), available water-holding capacity (AWHC), available phosphorous, extractable $\mathrm{K}$, $\mathrm{pH}$, electrical conductivity (EC), soil organic C (SOC), and microbial biomass carbon (MBC)), and overall averaged soil quality index (SQI) value (0 to 1 ), as affected by tillage system within the $5-15 \mathrm{~cm}$ depth increment (means $(n=4) \pm$ standard error).

\begin{tabular}{|c|c|c|c|}
\hline Soil Quality Indicator & No-Tillage & Minimum Tillage & Conventional Tillage \\
\hline \multicolumn{4}{|c|}{ Physical } \\
\hline $\mathrm{BD}\left(\mathrm{Mg} \mathrm{m}^{-3}\right)$ & $0.24 \mathrm{~b}$ & $0.25 \mathrm{ab}$ & $0.27 \mathrm{a}$ \\
\hline $\mathrm{PR}(\mathrm{MPa})$ & $0.74 \mathrm{a}$ & $0.63 \mathrm{a}$ & $0.76 \mathrm{a}$ \\
\hline MWDd (mm) & $0.60 \mathrm{a}$ & $0.60 \mathrm{a}$ & $0.68 \mathrm{a}$ \\
\hline \multicolumn{4}{|c|}{ Chemical } \\
\hline Total N $\left(\mathrm{g} \mathrm{kg}^{-1}\right)$ & $0.26 \mathrm{a}$ & $0.30 \mathrm{a}$ & $0.31 \mathrm{a}$ \\
\hline Available P (ppm) & $1.00 \mathrm{a}$ & $1.00 \mathrm{a}$ & $1.00 \mathrm{a}$ \\
\hline Extractable K (ppm) & $0.61 \mathrm{a}$ & $0.63 \mathrm{a}$ & $0.59 \mathrm{a}$ \\
\hline $\mathrm{CaCO}_{3}\left(\mathrm{~g} \mathrm{~kg}^{-1}\right)$ & $1.00 \mathrm{a}$ & $1.00 \mathrm{a}$ & $1.00 \mathrm{a}$ \\
\hline \multicolumn{4}{|c|}{ Organic matter and biological } \\
\hline $\mathrm{SOC}\left(\mathrm{g} \mathrm{kg}^{-1}\right)$ & $0.71 \mathrm{a}$ & $0.79 \mathrm{a}$ & $0.55 \mathrm{~b}$ \\
\hline $\operatorname{MBC}\left(\mathrm{mg} \mathrm{kg}^{-1}\right)$ & $0.08 \mathrm{a}$ & $0.11 \mathrm{a}$ & $0.06 \mathrm{a}$ \\
\hline \multicolumn{4}{|c|}{ Soil Quality Index (SQI) } \\
\hline & $0.64 \mathrm{a}$ & $0.65 \mathrm{a}$ & $0.64 \mathrm{a}$ \\
\hline
\end{tabular}

Treatment values within the same row followed by different letters are significantly different at $p<0.05$.

\section{Discussion}

\subsection{Soil Quality Indicator Selection—Dryland vs. Irrigated Soil Management}

Three years after the conversion to irrigation, the analysis of crop yields and $C$ returned to the soil, together with soil properties and their evaluation as SQ indicators, enabled us to evaluate the effect of this land use change by comparing the new SQ indicators selected as most sensitive to management with those from previous studies under dryland conditions at this site $[18,40,56]$. 
In relation to SQ indicators, we had hypothesized that their sensitivity to soil management may have changed because of the changes induced in the soil organic $\mathrm{C}$ cycle by the introduction of irrigation [46]. Results showed that many remained different between tillage systems after the adoption of irrigation (in particular, the two physical indicators (BD and PR), total N, extractable $\mathrm{K}, \mathrm{SOC}$ and earthworm biomass), as observed in rainfed conditions [18]. However, according to our hypothesis, there were some remarkable differences when measurements for dryland soils [18] were compared with those in irrigated soils, mostly in relation to POM-C and aggregate stability. Differences in POM-C between tillage treatments under dryland conditions were highly significant and resulted in that indicator being identified as the most sensitive to management in dryland conditions. These differences were reduced (significant at $p<0.10$ only at $0-5 \mathrm{~cm}$, Table 1 ) following the adoption of irrigation. Considering that crop yields and therefore $C$ returns to the soil did not change greatly with the adoption of irrigation, and were even among treatments, these differences can be understood as the consequence of the alteration of $C$ mineralization dynamics with irrigation. It is known that irrigation modifies SOC mineralization rates, as more water is available when temperatures are adequate for microbial degradation of organic matter [72], regardless of the tillage system used. Increased mineralization rates have indeed been reported as a reason for no changes in SOC stocks observed following irrigation adoption in the region in the short-term [46], and for SOC losses in the long-term in other semi-arid areas [52], most likely associated to improved soil moisture conditions and nutrients availability [73-75].

Aggregate stability was also a sensitive property under dryland conditions, and important for explaining differences between tillage treatments as it showed higher values with NT than MT or CT under non-irrigated conditions. However, in samples collected three years after irrigation was introduced, aggregate stability expressed as MWD was reduced in NT and differences between treatments were not significant, which seems related to the evolution of POM-C, as labile organic matter is known to be an active agent of macroaggregates stabilization [67]. Because of these changes, and because management decisions are known to affect soil properties in different ways, it was not surprising that the indicators identified as most sensitive to soil management under irrigated conditions differed from those under dryland conditions. For example, POM-C was no longer a meaningful indicator, while several others, such as BD, PR, SOC and earthworm biomass, remained sensitive for the $0-5 \mathrm{~cm}$ depth. Within the $5-15 \mathrm{~cm}$ depth, POM-C and aggregate stability (selected as the most sensitive indicators for this depth under dryland conditions) were replaced by BD and SOC. This change, however, still maintained a physical and an organic matter-related property as the most sensitive indicators with regard to SQ. These changes highlight the necessity of reevaluating SQ indicators when agroecosystems are changed. They also confirm observations by [19] that MDS indicators may need to change as climate, soil type, or even time, change. This is also in accordance with the current SQ paradigm, which focuses on evaluating the capacity of a soil to function within the limits of a determined ecosystem [11]. Furthermore, the short period in which changes occurred (only three years after irrigation was implemented) confirm the utility of previously selected indicators such as POM-C, which has been highlighted in the literature as an effective SQ indicator for detecting land use and soil management changes $[67,76,77]$. In this case, its behavior as a rapid indicator was confirmed by the fact that it changed in only three years, and was no longer selected as a significant indicator because it was no longer sensitive to differences in management under irrigation. As explained above, this is likely a consequence of similar amounts of crop residue being returned to the soil due to the lack of differences in yield, and also to the elimination of limitations for surface crop residues decomposition under NT when irrigation is applied to satisfy the crop water demand. Changes in other consequences of non-limiting moisture conditions, such as those associated to the priming effect of crop residues placed at different locations [78], are beyond the scope of this study but should be considered in future studies. 


\subsection{SMAF Soil Quality Index and Evaluation of Tillage Treatments}

The SMAF scores also indicated significant tillage effects on several soil properties. In relation to physical SQ, a significant increase in soil compaction, expressed by lower scores for $\mathrm{BD}$, was noted for the NT treatment. This effect had been previously observed in several NT studies [79,80]. Furthermore, according to SMAF interpretation, the low BD scores for all three tillage treatments indicated that the soil at this site would not be functioning at its full potential due to a possible compaction problem. BD data were in fact observed to be higher than generally described in cultivated soils in all the three treatments. As a result, BD scores for all three tillage treatments were quite low because the measured values (Table 1) all exceeded $1.5 \mathrm{Mg} \mathrm{m}^{-3}$, which is the threshold set by SMAF for limitations to SQ induced by elevated BD. However, previous studies in the area $[40,41,56]$ showed that agricultural soils of the type of the one studied here display values of BD ranging between 1.50 to $1.55 \mathrm{Mg} \mathrm{m}^{-3}$ under CT and $1.69-1.78 \mathrm{Mg} \mathrm{m}^{-3}$ under NT. These values are higher than those generally associated to limiting for soil crops when managed for agriculture, and yet these soils showed equal or higher yields under NT. This suggests that the scoring curves for BD need to be reconsidered if SMAF is to be used as a SQ assessment tool for soils such as those encountered in this study. This was supported by the lack of correlation between BD scores and the soil nutrient status. Some authors have described limitations to plant nutrition when BD exceeds certain values. For instance, Wolkowski et al. [81] described problems in $\mathrm{P}$ and $\mathrm{K}$ uptake efficiency by crops for values greater than $1.4 \mathrm{Mg} \mathrm{m}^{-3}$. Skopp et al. [82] reported critical bulk density for root penetration reported at values between 1.30 and $1.60 \mathrm{Mg} \mathrm{m}^{-3}$ for fine-textured soils. In the studied soil, NT, which had the lowest scores for BD (Tables 8 and 9), had the highest scores for $\mathrm{P}$ availability, and no differences were obtained in relation to extractable $\mathrm{K}$ between tillage systems (Table 8). No differences in yield were observed either.

In contrast to $\mathrm{BD}$, aggregate stability measurements appeared to be a better indicator of soil physical condition since the values were greater under NT $(16 \% \pm 0.1 \%)$ than either MT or CT, which averaged $12 \% \pm 2.1 \%$ at $0-5 \mathrm{~cm}$, and thus resulted in higher SMAF scores for NT than MT or CT (Table 8). Increased aggregate stability reflects better soil structure and supports the idea that the interpretation algorithm (i.e., scoring function) of BD may need to be revised based on inherent characteristics of soils in this region. Previous studies that used SMAF to compute a SQ index have also reported the sensitivity of WSA $[22,83]$ and BD $[4,83]$ as a SQ indicator, and observed score differences due to soil management for this soil property.

Increased WSA did not have a detectable effect on soil water retention characteristics (i.e., no differences were found in AWHC scores), but the overall score for physical indicators in SMAF were higher for NT than for MT or CT (Table 8). This was consistent with other studies that have shown improved aggregation within NT systems in the Mediterranean region [84-86], and have attributed this response to higher SOC concentrations and organic matter stability [87].

Among chemical indicators, only one (available P) showed differences among the tillage treatments for the $0-5 \mathrm{~cm}$ depth. Available P was not included in the MDS obtained through PCA because tillage differences were not significant. However, when the measurements were interpreted using the SMAF algorithms, the scored values were significantly different. This occurred because the observed $\mathrm{P}$ values were low and located in the exponential increase region of the scoring curve, where small increments of this property can result in big changes in the scores it gets (see [13]). Following the construction of SMAF algorithms, the observed low available P scores for CT would be translated in that plant-available P would be limiting for soil functioning with this management system. Conversely, the notably higher score for NT would indicate an improved chemical soil functioning. The absence of differences in yield, which is very sensitive to $P$ availability, suggests that this was not the case in the studied soil. At least two reasons can explain this lack of relationship between SMAF scores for available P and barley yields. First, in calcareous soils such as the one studied here, low P availability is common due to its retention by carbonates [34], leading to reduced P scores regardless of the tillage system. Second, the ability of plant roots to actually take up $P$ from the upmost soil layer $(0-5 \mathrm{~cm})$ can 
be questioned, as this layer is often dried out (even under irrigation) and the rooting density (one of the most important drivers for P uptake) is likely to be rather low at this depth.

From the chemical fertility perspective, the observed scores of 1 for extractable K (Tables 8 and 9), even though none was added in fertilizer, mean that the natural abundance of $K$ in this soil was high enough for the soil to function at its full potential. Therefore, the differences in extractable K observed between tillage treatments at $0-5$ (Table 1 ) disappeared when the values were interpreted by SMAF, since all were over the maximum established by the scoring curve.

For the organic and biological indicators (SOC and MBC), the SMAF scores indicated that both were close to the maximum possible score under NT at $0-5 \mathrm{~cm}$. In contrast, $\mathrm{CT}$ scores were low (near 0 in the case of $\mathrm{MBC}$ ), indicating the soil under this management was depleted in organic matter and its microbial community was very likely reduced and unable to accomplish at least some of their functions. Within the 5-15 cm depth, SOC scores were lower than within the $0-5 \mathrm{~cm}$ depth for NT and MT, although the scores of both those treatments were higher than for CT. These results provide further evidence that organic matter mineralization, enhanced by moldboard plowing, can induce a reduction of SOC that can affect soil functioning at this depth. It is also remarkable how dramatically MBC scores decreased for all tillage treatments below the $0-5 \mathrm{~cm}$ depth: the $\mathrm{MBC}$ scores were near zero for all tillage systems, emphasizing the reduced presence of microorganisms below the first $5 \mathrm{~cm}$ within the studied soil. The importance of SOC as a SQ indicator is consistent with previous studies using SMAF, which showed high SOC score differences between management practices $[4,83]$. SOC also had low SMAF scores in several of the soils evaluated in other studies $[22,23,83]$ indicating that agricultural soils are frequently depleted in organic matter. This further emphasizes the value of using SOC as an indicator to detect agricultural soil-improving management practices.

Finally, the overall SQ index calculated using SMAF was significantly different between the three managements at $0-5 \mathrm{~cm}$, but not at $5-15 \mathrm{~cm}$. The ranking of the scores for the surface $5 \mathrm{~cm}$ was NT $>$ MT > CT. Data presented in Table 8 indicate that the higher NT index was mostly due to better scores for aggregate stability, available P, SOC and MBC. Comparing these results with other studies is complicated, as SQ evaluation indexes need to be compared not only using similar calculation methods, but also for soils with the same inherent characteristics. A study [24] also evaluated different long-term tillage effects using SMAF under non-irrigated conditions in Iowa. Despite the differences in agronomy and climate, they observed, in accordance with our results, the lowest scores in soils under moldboard tillage, which had the most negative impact on several SQ indicators. In addition, in agreement with our observations WSA, SOC and MBC were the indicators with the highest differences between managements. In the second soil depth $(5-15 \mathrm{~cm})$, both the available P concentration and MBC decreased dramatically under NT in the current study. Consequently, no differences in the SQ index provided by SMAF were found in that depth.

\subsection{Adequacy of $S M A F$}

The results obtained when applying SMAF algorithms to our data can be evaluated from two perspectives. First, in relation to the overall SQ index scores based on our SMAF evaluation of the studied soil, they were in the range 0.64 to 0.76 (in a scale from 0 to 1 ). These results are low in comparison with the results found in the literature based on previous SQ studies using SMAF analysis. For example, Karlen et al. [22] evaluated different crop rotations in a study carried out in three different sites located in Iowa and Wisconsin. They found scores higher than 0.90, 0.80 and 0.75 in each site for the $0-15 \mathrm{~cm}$ soil depth. Stott et al. [23] studied areas with different crop development conditions in several soils along the Iowa River's South Fork Watershed. They found average SMAF scores of 0.86 and 0.82 for well-developed and poorly-developed crop canopy areas, respectively, in the $0-10 \mathrm{~cm}$ soil depth. In studies where soil samples were divided in different depths, average SMAF scores obtained for the $0-5 \mathrm{~cm}$ soil depth were always over $0.80[4,24,83]$. In our results, the scores obtained in the 5-15 cm depth were lower than within the $0-5 \mathrm{~cm}$ depth in all cases. This was also observed in previous studies, although our values were generally lower than those reported 
elsewhere $[24,83]$. The scores for the $5-15 \mathrm{~cm}$ depth obtained in [4] $(0.53-0.69)$, were the only ones within the same range of those obtained in this study. All the studies mentioned were performed in soils located in the Midwestern U.S., and comparisons with results for our climatic conditions must be carefully considered. The systematically low values obtained in our study, for a soil that is irrigated and achieving average yield standards suggest that, despite the flexibility of SMAF to adapt its algorithms to different soils and ecosystem conditions, a calibration of the tool for different regional conditions is probably needed. This would help validate the scores given by SMAF, especially those who primarily focus on crop yield response.

Second, it should be noted that crop yields, which were recorded as an indicator of soil functioning because sustaining plant productivity is considered the major soil function for irrigated agricultural soils in the study area, were not different between tillage systems. The observed differences in SQ indicators scores and SQ indexes between tillage treatments did not, therefore, have a detectable effect on barley yield. In this context, it seems necessary to consider whether this type of assessments are actually evaluating the real functioning capacity of different agro-ecosystems, and are able to detect differences in soil condition beyond their effect on yields. SMAF, as used in the studied semi-arid irrigated Mediterranean soil, was able to detect significant differences in many SQ indicators, which were sensitive enough to differentiate among tillage managements. The absence of correlation with barely yields can be explained by the fact that external inputs (fertilizers and irrigation water) minimized soil effects limiting crop productivity. In addition, the slightly better soil physical condition for BD observed under CT than NT (Tables 8 and 9) can help to explain similar production among treatments. This is in contrast with yield differences found in dry seasons under dryland conditions at this site [56], when an increase in AWHC was considered the main advantage for NT. The implementation of irrigation, which greatly reduces the importance of this advantage and has resulted in no differences in AWHC between soil systems after three years of irrigation, is very likely related to the absence of yield differences.

\section{Conclusions}

In an attempt to systematically evaluate SQ indicators in Mediterranean semi-arid irrigated cropland under different soil managements, factor analysis showed that, although some indicators selected previously in dryland conditions were still valid, the most sensitive indicators changed both at $0-5$ and $5-15 \mathrm{~cm}$. This supported our hypothesis that irrigation, even when it does not result in immediate increases in crop yields, can induce changes in soil functioning that result in the need of re-assessing the utility of SQ indicators. In addition, it showed that changes induced in SQ by different dryland tillage systems might be reverted in just three years, when the soil is irrigated. The early sensitivity associated to some SQ indicators, especially POM-C, was also confirmed because POM-C was no longer able to detect differences between tillage systems only three years after irrigation was introduced. These results highlight the necessity of accurate evaluations of the consequences of such a change in soils, especially considering that the transformation to irrigation is affecting millions of ha worldwide, under the pressure of increasing productivity without increasing the total surface of cultivated land.

Following our second hypothesis, the SMAF framework was shown to be sensitive and able to detect differences in SQ indicators between tillage treatments in irrigated Mediterranean land. However, the low scores obtained by some soil properties in SMAF, and the overall low soil quality obtained by the studied soil, suggest that a detailed analysis and possible interpretation changes may be necessary to adapt some SMAF algorithms for local agroclimate. This seems especially important for indicators such as $\mathrm{BD}$, which consistently returned low values.

Acknowledgments: C. González, D. Maiz, I. de Soto, and I. Urrutia are thanked for their help in field and laboratory tasks. We thank the Spanish National Institute of Agricultural Research (INIA) and FEDER European founds for the funding of Project RTA2009-00052-C02-00 and M. Apesteguía Ph.D. scholarship. We thank the two anonymous reviewers and the editor for their help in improving the quality of the manuscript. 
Author Contributions: Iñigo Virto, Luis Orcaray, Paloma Bescansa and Alberto Enrique conceived and designed the experiments; Marcos Apesteguía and Iñigo Virto performed the experiments; and Marcos Apesteguía, Iñigo Virto, María José Imaz and Douglas L. Karlen analyzed the data and wrote the paper.

Conflicts of Interest: The authors declare no conflict of interest.

\section{References}

1. Andrews, S.S.; Karlen, D.L.; Mitchell, J.P. A comparison of soil quality indexing methods for vegetable production systems in Northern California. Agric. Ecosyst. Environ. 2002, 90, 25-45. [CrossRef]

2. Sharma, K.L.; Kusuma, G.J.; Uttam, K.M.; Gajbhiye, P.N.; Srinivas, K.; Korwar, G.R.; Hima Bindu, V.; Ramesh, V.; Kausalaya Ramachandran, Y.S.K. Evaluation of long-term soil management practices using key indicators and soil quality indices in a semi-arid tropical Alfisol. Aust. J. Soil Res. 2008, 46, 368-377. [CrossRef]

3. Aziz, I.; Mahmood, T.; Islam, K.R. Effect of long term no-till and conventional tillage practices on soil quality. Soil Tillage Res. 2013, 131, 28-35. [CrossRef]

4. Karlen, D.L.; Birrell, S.J.; Hess, J.R. A five-year assessment of corn stover harvest in Central Iowa, USA. Soil Tillage Res. 2011, 115-116, 47-55. [CrossRef]

5. Yao, R.; Yang, J.; Gao, P.; Zhang, J.; Jin, W. Determining minimum data set for soil quality assessment of typical salt-affected farmland in the coastal reclamation area. Soil Tillage Res. 2013, 128, 137-148. [CrossRef]

6. Carter, M.R.; Gregorich, E.G.; Anderson, D.W.; Doran, J.W.; Janzen, H.H.; Pierce, F.J. Concepts of soil quality and their significance. In Soil Quality for Crop Production and Ecosystem Health; Gregorich, E.G., Carter, M., Eds.; Elsevier Science Publishers: Amsterdam, The Netherlands, 1997; pp. 1-17.

7. Karlen, D.L.; Ditzler, C.A.; Andrews, S.S. Soil quality, why and how? Geoderma 2003, 114, 145-156. [CrossRef]

8. Karlen, D.L.; Mausbach, M.J.; Doran, J.W.; Cline, R.G.; Harris, R.F.; Schuman, G.E. Soil quality, a concept, definition, and framework for evaluation. Soil Sci. Soc. Am. J. 1997, 61, 4-10. [CrossRef]

9. Singer, M.; Erwin, S. Soil quality. In Handbook of Soil Science; Sumner, M.E., Ed.; CRC Press: Boca Raton, FL, USA, 2000; pp. G271-G298.

10. Larson, W.E.; Pierce, F.J. Conservation and enhancement of soil quality. In Proceedings of the International Workshop on Evaluation for Sustainable Land Management in the Developing World, Chiang Rai, Thailand, 15-21 September 1991.

11. Doran, J.W.; Parkin, T.B. Defining and assessing soil quality. In Defining Soil Quality for a Sustainable Environment; Doran, J.W., Coleman, D.C., Bezdicek, D.F., Stewart, B.A., Eds.; SSSA Special Publication: Madison, WI, USA, 1994; pp. 3-21.

12. Harris, R.F.; Karlen, D.L.; Mulla, D.J. A conceptual framework for assessment and management of soil quality and health. In Methods for Assessing Soil Quality; Doran, J.W., Jones, A.J., Eds.; Soil Science Society of America: Madison, WI, USA, 1996; pp. 61-82.

13. Andrews, S.S.; Karlen, D.L.; Cambardella, C.A. The soil management assessment framework, a quantitative soil quality evaluation method. Soil Sci. Soc. Am. J. 2004, 68, 1945-1962. [CrossRef]

14. Govaerts, B.; Sayre, K.D.; Deckers, J. A minimum data set for soil quality assessment of wheat and maize in the highlands of Mexico. Soil Tillage Res. 2006, 87, 163-174. [CrossRef]

15. Rezaei, S.A.; Gilkes, R.J.; Andrews, S.S. A minimum data set for assessing soil quality in rangelands. Geoderma 2006, 136, 229-234. [CrossRef]

16. Shukla, M.K.; Lal, R.; Ebinger, M. Determining soil quality indicators by factor analysis. Soil Tillage Res. 2006, 87, 194-204. [CrossRef]

17. Yemefack, M.; Jetten, V.G.; Rossiter, D.G. Developing a minimum data set for characterizing soil dynamics in shifting cultivation Systems. Soil Tillage Res. 2006, 86, 84-98. [CrossRef]

18. Imaz, M.J.; Virto, I.; Bescansa, P.; Enrique, A.; Fernández-Ugalde, O.; Karlen, D.L. Soil quality indicator response to tillage and residue management on semi-arid Mediterranean cropland. Soil Tillage Res. 2010, 107, 17-25. [CrossRef]

19. Andrews, S.S.; Carroll, C.R. Designing a soil quality assessment tool for sustainable agroecosystem management. Ecol. Appl. 2001, 11, 1573-1585. [CrossRef] 
20. Andrews, S.S.; Mitchell, J.P.; Mancincelli, R.; Karlen, D.L.; Hartz, T.H.; Horwath, W.R.; Pettygrove, S.; Scow, K.M.; Munk, D. On-farm assessment of soil quality in California's Central Valley. Agron. J. 2002, 94, 12-23. [CrossRef]

21. Zobeck, T.M.; Halvorson, A.D.; Wienhold, B.J.; Acosta-Martinez, V.; Karlen, D.L. Comparison of two soil quality indexes to evaluate cropping systems in northern Colorado. J. Soil Water Conserv. 2008, 63, 329-338. [CrossRef]

22. Karlen, D.L.; Hurley, E.G.; Andrews, S.S.; Cambardella, C.A.; Meek, D.W.; Duffy, M.D.; Mallarino, A.P. Crop rotation effects on soil quality at three northern corn/soybean belt locations. Agron. J. 2006, 98, 484-495. [CrossRef]

23. Stott, D.E.; Cambardella, C.A.; Tomer, M.D.; Karlen, D.L.; Wolf, R. A soil quality assessment within the Iowa River South Fork watershed. Soil Sci. Soc. Am. J. 2011, 75, 2271-2282. [CrossRef]

24. Karlen, D.L.; Kovar, J.L.; Camabradella, C.A.; Colvin, T.S. Thirty-year tillage effects on crop yield and soil fertility indicators. Soil Tillage Res. 2013, 130, 24-41. [CrossRef]

25. Wienhold, B.J.; Karlen, D.L.; Andrews, S.S.; Stott, D.E. Protocol for indicator scoring in the soil management assessment framework (SMAF). Renew. Agric. Food Syst. 2009, 24, 260-266. [CrossRef]

26. Bhaduri, D.; Purakayastha, T.J. Long-term tillage, water and nutrient management in rice-wheat cropping system: Assessment and response of soil quality. Soil Tillage Res. 2014, 144, 83-95. [CrossRef]

27. Kalu, S.; Koirala, M.; Khadka, U.R.; Anup, K.C. Soil quality assessment for different land use in the panchase area of Western Nepal. Int. J. Environ. Prot. 2015, 5, 38-43. [CrossRef]

28. Ozgoz, E.; Gunal, H.; Acir, N.; Gokmen, F.; Birol, M.; Budak, M. Soil quality and spatial variability assessment of land use effects in a Typici Haplustoll. Land Degrad. Dev. 2013, 24, 277-286. [CrossRef]

29. Cherubin, M.R.; Karlen, D.L.; Franco, A.L.C.; Cerri, C.E.P.; Tormena, C.A.; Cerri, C.C. A Soil Management Assessment Framework (SMAF) evaluation of Brazilian sugarcane expansion on soil quality. Soil Sci. Soc. Am. J. 2016, 80, 215-226. [CrossRef]

30. Wienhold, B.J.; Pikul, J.L., Jr.; Liebig, M.A.; Mikha, M.M.; Varvel, G.F.; Doran, J.W.; Andrews, S.S. Cropping system effects on soil quality in the Great Plains: Synthesis from a regional project. Renew. Agric. Food Syst. 2006, 21, 49-59. [CrossRef]

31. Karlen, D.L.; Andrews, S.S.; Wienhold, B.J.; Zobeck, T.M. Soil quality assessment, past, present and future. J. Integr. Biosci. 2008, 6, 3-14.

32. Sánchez-Navarro, A.; Gil-Vázquez, J.M.; Delgado-Iniesta, M.J.; Marín-Sanleandro, P.; Blanco-Bernardeu, A.; Ortiz-Silla, R. Establishing an index and identification of limiting parameters for characterizing soil quality in Mediterranean ecosystems. Catena 2015, 131, 35-45. [CrossRef]

33. Lal, R.; Kimble, J.M. Pedogenic carbonates and the global C cycle. In Global Change and Pedogenic Carbonates; Lal, R., Kimble, J.M., Eswaran, H., Stewart, B.A., Eds.; Lewish Publishers: Boca Raton, FL, USA, 2000; pp. 43-64.

34. Díaz, I.; Torrent, J. Changes in Olsen P in relation to $\mathrm{P}$ balance in contrasting agricultural soils. Pedosphere 2016, 26, 636-642. [CrossRef]

35. Audette, Y.; O'Halloran, I.P.; Voroney, R.P. Kinetics of phosphorus forms applied as inorganic and organic amendments to a calcareous soil. Geoderma 2016, 262, 119-124. [CrossRef]

36. Abiven, S.; Menasseri, S.; Chenu, C. The effects of organic inputs over time on soil aggregate stability-A literature analysis. Soil Biol. Biochem. 2009, 41, 1-12. [CrossRef]

37. Boix-Fayos, C.; Calvo-Cases, A.; Imeson, A.C.; Soriano-Soto, M.D. Influence of soil properties on the aggregation of some Mediterranean soils and the use of aggregate size and stability as land degradation indicators. Catena 2001, 44, 47-67. [CrossRef]

38. Fernández-Ugalde, O.; Virto, I.; Barré, P.; Gartzia-Bengoetxea, N.; Enrique, A.; Imaz, M.J.; Bescansa, P. Effect of carbonates on the hierarchical model of aggregation in calcareous semi-arid Mediterranean soils. Geoderma 2011, 164, 203-214. [CrossRef]

39. Fernández-Ugalde, O.; Virto, I.; Barré, P.; Apesteguía, M.; Enrique, A.; Imaz, M.J.; Bescansa, P. Mechanisms of macroaggregate stabilisation by carbonates: Implications for organic matter protection in semi-arid calcareous soils. Soil Res. 2014, 52, 180-192. [CrossRef]

40. Virto, I.; Imaz, M.J.; Enrique, A.; Hoogomed, W.; Bescansa, P. Burning crop residues under no-till in semi-arid land, Northern Spain-Effects on soil organic matter, aggregation and earthworm populations. Aust. J. Soil Res. 2007, 45, 414-421. [CrossRef] 
41. Fernández-Ugalde, O.; Virto, I.; Bescansa, P.; Imaz, M.J.; Enrique, A.; Karlen, D.L. No-tillage improvement of soil physical quality in calcareous, degradation-prone, semiarid soils. Soil Tillage Res. 2009, 106, 29-35. [CrossRef]

42. Rixon, A. Soil fertility changes in a red-brown earth under irrigated pastures. I. Changes in organic carbon/nitrogen ratio, Cation exchange capacity and pH. Crop. Pasture Sci. 1966, 17, 317-325. [CrossRef]

43. McDowell, R.W.; van der Weerden, T.J.; Campbell, J. Nutrient losses associated with irrigation, intensification and management of land use: A study of large scale irrigation in North Otago, New Zealand. Agric. Water Manag. 2011, 98, 877-885. [CrossRef]

44. Manono, B.O. Carbon dioxide, nitrous oxide and methane emissions from the Waimate District (New Zealand) pasture soils as influenced by irrigation, effluent dispersal and earthworms. Cogent Environ. Sci. 2016, 2. [CrossRef]

45. Manono, B.O.; Moller, H. Effects of stock type, irrigation and effluent dispersal on earthworm species composition, densities and biomasses in New Zealand pastures. Pedobiologia 2015, 58, 187-193. [CrossRef]

46. Apesteguía, M.; Virto, I.; Orcaray, L.; Enrique, A.; Bescansa, P. Effects of the conversion to irrigation of semiarid Mediterranean dryland agroecosystems on soil carbon dynamics and soil aggregation. Arid Land Res. Manag. 2015, 29, 339-414. [CrossRef]

47. De Soto, I.S.; Virto, I.; Barré, P.; Fernández-Ugalde, O.; Antón, R.; Martínez, I.; Chaduteau, C.; Enrique, A.; Bescansa, P. A model for field-based evidences of the impact of irrigation oncarbonates in the tilled layer of semi-arid Mediterranean soils. Geoderma 2017, 297, 48-60. [CrossRef]

48. Entry, J.A.; Sojka, R.; Shewmaker, G.E. Management of irrigated agriculture to increase organic carbon storage in soils. Soil Sci. Soc. Am. J. 2002, 66, 1957-1964. [CrossRef]

49. Denef, K.; Stewart, C.E.; Brenner, J.; Paustian, K. Does long-term center-pivot irrigation increase soil carbon stocks in semiarid agro-ecosystems? Geoderma 2008, 145, 121-129. [CrossRef]

50. Follett, R.F.; Castellanos, J.Z.; Buenger, E.D. Carbon dynamics in an irrigated Vertisol in Central Mexico. Soil Tillage Res. 2005, 83, 148-158. [CrossRef]

51. Follett, R.F.; Jantalia, C.P.; Halvorson, A.D. Soil carbon dynamics for irrigated corn under two tillage systems. Soil Sci. Soc. Am. J. 2013, 77, 951-963. [CrossRef]

52. Nunes, J.M.; López-Piñeiro, A.; Albarrán, A.; Muñoz, A.; Coelho, J. Changes in selected soil properties caused by 30 years of continuous irrigation under Mediterranean conditions. Geoderma 2007, 139, 321-328. [CrossRef]

53. Álvaro-Fuentes, J.; Paustian, K. Potential soil carbon sequestration in a semiarid Mediterranean agroecosystem under climate change: Quantifying management and climate effects. Plant Soil 2011, 338, 261-272. [CrossRef]

54. Muñoz-Rojas, M.; Abd-Elmabod, S.K.; Zavala, L.M.; de la Rosa, D.; Jordán, A. Climate change impacts on soil organic carbon stocks of Mediterranean agricultural areas: A case study in Northern Egypt. Agric. Ecosyst. Environ. 2017, 238, 142-152. [CrossRef]

55. Houlbrooke, D.; Littlejohn, R.; Morton, J.; Paton, R. Effect of irrigation and grazing animals on soil quality measurements in the North Otago Rolling Downlands of New Zealand. Soil Use Manag. 2008, 24, 416-423. [CrossRef]

56. Bescansa, P.; Imaz, M.J.; Virto, I.; Enrique, A.; Hoogmoed, W.B. Soil water retention capacity as affected by tillage systems under semiarid conditions in Navarra (NE Spain). Soil Tillage Res. 2006, 87, 19-27. [CrossRef]

57. IUSS Working Group WRB. International Soil Classification System for Naming Soils and Creating Legends for Soil Maps; World Reference Base for Soil Resources 2014, Update 2015; World Soil Resources Reports No. 106; FAO: Food and Agriculture Organization: Rome, Italy, 2015; p. 192.

58. Thornthwaite, C.W. An approach toward a national classification of climate. Geophys. Rev. 1948, 38, 55-94.

59. INTIA Recomendaciones de Riego 2017. Available online: https://www.intiasa.es/en/comunidad-deregantes/areas-de-interes/servicio-asesoramiento-al-regante/recomendaciones-de-riego.html (accessed on 26 July 2017). (In Spanish)

60. Intergovernmental Panel on Climate Change (IPCC). Agriculture, forestry and other land use. In Guidelines for National Greenhouse Gas Inventories; Intergovernmental Panel on Climate Change: Geneva, Switzerland, 2006; Available online: http:/ / www.ipcc-nggip.iges.or.jp/public/2006gl/vol4.html (accessed on 26 July 2017).

61. Culley, J.L.B. Density and compressibility. In Soil Sampling and Methods of Analysis; Carter, M.R., Ed.; CRC Press LLC: Boca Raton, FL, USA, 1993; pp. 529-539. 
62. Lehmann, J.; Cravo, M.S.; Zech, W. Organic matter stabilization in a Xanthic Ferralsol of the central Amazon as affected by single trees, chemical characterization of density, aggregate, and particle size fractions. Geoderma 2001, 99, 147-168. [CrossRef]

63. Franzluebbers, A.J. Water infiltration and soil structure related to organic matter and its stratification with depth. Soil Tillage Res. 2002, 66, 197-205. [CrossRef]

64. Olsen, S.R.; Sommers, L.E. Phosphorous. In Methods of Soil Analysis, 2nd ed.; Page, A.L., Miller, R.H., Keeney, D.R., Eds.; ASA Agronomy Series No. 9; Soil Science Society of America: Madison, WI, USA, 1982; pp. 421-422.

65. Knudsen, D.; Peterson, G.A.; Pratt, P.F. Lithium, sodium, potassium. In Methods of Soil Analysis, 2nd ed.; Page, A.L., Miller, R.H., Keeney, D.R., Eds.; ASA Agronomy Series No. 9; Soil Science Society of America: Madison, WI, USA, 1982; pp. 225-246.

66. Nelson, D.W.; Sommers, L.E. Total carbon, organic carbon and organic matter. In Methods of Soils Analysis, 2nd ed.; Page, A.L., Miller, R.H., Keeney, D.R., Eds.; Soil Science Society of America and Agronomy Society of America: Madison, WI, USA, 1982; pp. 539-579.

67. Cambardella, C.A.; Elliot, E.T. Particulate soil organic-matter changes across a grassland cultivation sequence. Soil Sci. Soc. Am. J. 1992, 56, 777-783. [CrossRef]

68. Baker, G.H.; Lee, K.E. Earthworms. In Soil Sampling and Methods of Analysis; Carter, M.R., Ed.; Canadian Society of Soil Science and Lewis Publishers: Boca Raton, FL, USA, 1993; pp. 359-371.

69. Bescansa, P.; Virto, I.; Fernández-Ugalde, O.; Imaz, M.J.; Enrique, A. Casting activity of Scherotheca gigas in no-till Mediterranean soils: Role in organic matter incorporation and influence of aridity. Appl. Environ. Soil Sci. 2010. [CrossRef]

70. Vance, E.D.; Brookes, P.C.; Jenkinson, D.S. An extraction method for measuring soil microbial biomass C. Soil Biol. Biochem. 1987, 19, 703-704. [CrossRef]

71. Brejda, J.J.; Moorman, T.B.; Karlen, D.L.; Dao, T.H. Identification of regional soil quality factors and indicators, I. Central and Southern High Plains. Soil Sci. Soc. Am. J. 2000, 64, 2115-2124. [CrossRef]

72. Gillabel, J.; Denef, K.; Brenner, J.; Merckx, R.; Paustian, K. Carbon sequestration and soil aggregation in center-pivot irrigated and dryland cultivated farming systems. Soil Sci. Soc. Am. J. 2007, 71, 1020-1028. [CrossRef]

73. Cotton, J.; Acosta-Martínez, V.; Moore-Kucera, J.; Burow, G. Early changes due to sorghum biofuel cropping systems in soil microbial communities and metabolic functioning. Biol. Fertil. Soil 2013, 49, 403-413. [CrossRef]

74. Holland, T.C.; Reynolds, A.G.; Bowen, P.A.; Bogdanoff, C.P.; Marciniak, M.; Brown, R.B.; Hart, M.M. The response of soil biota to water availability in vineyards. Pedobiologia 2013, 56, 9-14. [CrossRef]

75. Zhang, X.M.; Wei, H.W.; Chen, Q.S.; Han, X.G. The counteractive effects of nitrogen addition and watering on soil bacterial communities in a steppe ecosystem. Soil Biol. Biochem. 2014, 72, 26-34. [CrossRef]

76. Jastrow, J.D. Soil aggregate formation and the accrual of particulate and mineral-associated organic matter. Soil Bio. Biochem. 1996, 28, 665-676. [CrossRef]

77. Marquez, C.O.; Cambardella, C.A.; Isenhart, T.M.; Schultz, R.C. Assessing soil quality in a riparian buffer by testing organic matter fractions in central Iowa, USA. Agrofor. Syst. 1999, 44, 133-140. [CrossRef]

78. Bell, J.M.; Smith, J.L.; Bailey, V.L.; Bolton, H. Priming effect and C storage in semi-arid no-till spring crop rotations. Biol. Fertil. Soil 2003, 37, 237-244.

79. Mahboubi, A.A.; Lal, R.; Faussey, N.R. Twenty-eight years of tillage effects on two soils in Ohio. Soil Sci. Soc. Am. J. 1993, 57, 506-512. [CrossRef]

80. Lampurlanés, J.; Cantero-Martinez, C. Soil bulk density and penetration resistance under different tillage and crop management systems and their relationship with barley root growth. Agron. J. 2003, 95, 526-536. [CrossRef]

81. Wolkowski, R.P. Relationship between wheel-traffic-induced soil compaction, nutrient availability, and crop growth: A review. J. Prod. Agric. 1990, 3, 460-469. [CrossRef]

82. Skopp, J.M. Physical properties of primary particles. In Handbook of Soil Science; Sumner, M.E., Ed.; CRC Press: Boca Raton, FL, USA, 1999; pp. 3-17.

83. Jokela, W.E.; Grabber, J.E.; Karlen, D.L.; Balser, T.C.; Palmquist, D.E. Cover crop and liquid manure effects on soil quality indicators in a corn silage system. Agron. J. 2009, 101, 727-737. [CrossRef] 
84. Mrabet, R.; Saber, N.; El-Brahli, A.; Lahlou, S.; Bessam, F. Total, particulate organic matter and structural stability of a Calcixeroll soil under different wheat rotations and tillage systems in a semiarid area of Morocco. Soil Tillage Res. 2001, 57, 225-235. [CrossRef]

85. Álvaro-Fuentes, J.; Arrúe, J.L.; Gracia, R.; López, M.V. Soil management effects on aggregate dynamics in semiarid Aragon (NE Spain). Sci. Total Environ. 2007, 378, 179-182. [CrossRef] [PubMed]

86. Álvaro-Fuentes, J.; Arrúe, J.L.; Cantero-Martínez, C.; López, M.V. Aggregate breakdown during tillage in a Mediterranean loamy soil. Soil Tillage Res. 2008, 101, 62-68. [CrossRef]

87. Álvaro-Fuentes, J.; Cantero-Martínez, C.; López, M.V.; Paustian, K.; Denef, K.; Stewart, C.E.; Arrúe, J.L. Soil aggregation and soil organic carbon stabilization, effects of managements in semiarid Mediterranean agroecosystems. Soil Sci. Soc. Am. J. 2009, 73, 1519-1529. [CrossRef]

2017 by the authors. Licensee MDPI, Basel, Switzerland. This article is an open access article distributed under the terms and conditions of the Creative Commons Attribution (CC BY) license (http://creativecommons.org/licenses/by/4.0/). 